\title{
MENINGKATKAN KEMAMPUAN MENULIS DALAM PEMBELAJARAN BAHASA INDONESIA MELALUI MODEL EXAMPLE NON EXAMPLE DI KELAS V SEKOLAH DASAR NEGERI MEDAN
}

\author{
Eva Betty Simanjuntak, Lili Husaini
}

Surel : evabettysimanjuntak@yahoo.co.id

\begin{abstract}
ABSTRAK
Penelitian ini bertujuan untuk meningkatkan kemampuan menulis sisiwa pada materi Menulis Teks Deskripsi melalui model Example Non Example di kelas V SD Negeri 101797 Delitua. Jenis penelitian ini adalah Penelitian Tindakan Kelas (PTK). Subjek penelitian ini adalah kelas V SD yang berjumlah 30 orang siswa yang terdiri dari 15 perempuan dan 15 laki-laki. Teknik pengumpulan data dalam penelitian ini berupa tes kemampuan menulis siswa, dan observasi guru dan siswa. Penelitian Tindakan Kelas ini terdiri dari 2 siklus. Pada hasil post tes siklus I nilai rata-rata meningkat menjadi 62,63 dengan rentan peningkatan sebanyak $12,29 \%$. Pada hasil post tes siklus II nilai rata-rata siswa meningkat menjadi 70,27 dengan rentan peningkatan mencapai $7,64 \%$ sedangakan observasi peningkatan aktivitas belajar siswa pada siklus I sebesar $75,45 \%$, dan pada siklus II sebesar $81,81 \%$ artinya terjadi peningkatan sebesar 6,36\% dari siklus I hingga siklus II.
\end{abstract}

Kata Kunci: Menulis, Teks Deskripsi, Model Example Non Example

\section{PENDAHULUAN}

Pembelajaran Bahasa

Indonesia mengalami perkembangan yang pesat. Berbagai pendekatan, strategi, pembelajaran dan media pembelajaran Bahasa Indonesia yang inovatif dan variatif mulai diterapkan para guru Bahasa Indonesia tujuan adanya perubahan pola pembelajaran tersebut adalah dalam rangka pencapaian kompetensi siswa dalam bidang-bidang tertentu. Penguasaan keterampilan dalam bidang Bahasa Indonesia juga turut mendapat perhatian.Keterampilan berbahasa bukan lagi hanya untuk diketahui, melainkan untuk dikuasai oleh siswa. Menulis merupakan kegiatan yang paling kompleks dan produktif.
Untuk keterampilan menulis, ketiga keterampilan di bawahnya haruslah saling mendukung. Keterampilan menulis merupakan suatu keterampilan berbahasa yang digunakan untuk berkomunikasi secara tidak langsung. Dengan keterampilan itu, seseorang dapat mengungkapkan ide, pikiran, perasaan, dan kemampuannya kepada orang lain melalui tulisan. Penting sekali penataan bahasa maupun kalimat dalam tulisan yang disusun harus memenuhi kriteria penulisan bahasa yang baik dan benar.

Dalman (2015:1) berpendapat bahwa "menulis merupakan salah satu kegiatan kreatif berupa 

penuangan gagasan, angan-angan, perasaan dalam sebuah tulisan yang dihasilkan oleh penulis". Dalam hal ini menulis bukanlah pekerjaan yang ringan dan bukan juga pekerjaan yang berat, kegiatan menulis tidak dapat seperti membalikkan kedua telapak tangan karena menulis itu harus melaui proses.

Nurgiyantoro (2013: 422), Menulis merupakan proses pengungkapan ide, gagasan, pikiran, maupun perasaan yang dituangkan melalui tulisan. Kompetensi menulis lebih sulit dibanding tiga kompetensi bahasa yang lain pengungkapan ide atau gagasan yang dimaksudkan sebagai wacana yang telah disusun di dalam pikiran maupun angan-angan yang kemudian dituangkan kedalam bentuk tulisan yang tepat. Hermer (2001:14) Writing is a series of activities going on and involves several phases, the preparatory phase, and the content development and review, as well as revisions or improvements posts.

Hartig (Tarigan, 2005: 22), tujuan menulis yaitu: 1) assigament purpose (tujuan penugasan),Penulis menulis sesuatu karena ditugaskan untuk menulis, misalnya para siswa diberi tugas untuk mencatat materi pelajaran buku, sekretaris yang ditugaskan untuk membuat notulen rapat. 2) altruistic purpose (tujuan altruistik),Tulisan yang bertujuan untuk menyenangkan para pembaca.

3) persuasive purpose (tujuan persuasif), Tulisan yang bertujuan meyakinkan para pembaca akan kebenaran gagasan yang diutarakan.
4) informational purpose (tujuan informasional, tujuan penerangan). Tulisan yang bertujuan memberi informasi atau keterangan/ penerangan kepada para pembaca. 5) self-expressive purpose (tujuan pernyataan diri),Tulisan yang bertujuan memperkenalkan atau menyatakan diri sang pengarang kepada para pembaca. 6) creative purpose (tujuan kreatif),Tulisan yang bertujuan mencapai nilai-nilai artistik, nilai-nilai kesenian. dan 7) problemsolving purpose (tujuan pemecahan masalah, Tulisan yang tertujuan untuk memecahkan masalah yang dihadapi agar dapat dimengerti pembaca. Menurut Friedman (2010) descriptive detail mean to grap the reader's attantion. A descriptive text is considered as the simplest and easist writing form compared to narrative, recount, or procedure, particularly for the beginning writers.

Penulisan teks deskripsi yang dikatakan lebih mudah dibandingkan dengan penulisan teks yang lainnya tetap saja memiliki kesulitan tertentu serta kemampuan yang baik bagi penulisnya. Penulisan teks deskripsi tidak hanya sekedar mengenai kemampuan menggambarkan atau melukiskan objek ke dalam bentuk tulisan secara rinci, namun beberapa aturan juga perlu diperlu diperhatikan dalam penulisan teks deskripsi, seperti yang dikatakan oleh Nurgiyantoro (2005: 76) mengenai hal-hal yang harus diperhatikan dalam mengetahui kemampuan menulis 
teks deskripsi, berikut indikatorindikator dalam tes menulis teks deskripsi: 1) isi karangan, meliputi kesesuaian isi karangan sehingga bermakna, menarik, tepat, dan memiliki jalan pikiran yang baik dalam pengembangannya. 2) organisasi karangan, meliputi kerapian dalam penyusunan paragraf, ketepatan pemakaian kalimat topik, organisasi meyakinkan, alur karangan mudah diikuti. 3) penggunaan Bahasa, meliputi penggunaan kalimat sudah dapat dikatakan benar, kata yang dipilih tidak memiliki makna ganda. 4) penggunaan ejaan dan tanda baca, meliputi kesesuaian pemakaian ejaan dengan tanda baca, serta ketepatan penulisan suku kata.

Berdasarkan indikator menulis teks deskripsi di atas maka dapat disimpulkan bahwa kemampuan siswa dalam menuliskan teks deskripsi apabila siswa sudah mampu menyesuaikan isi karangan sehingga bermakna, menarik, tepat dalam pemilihan kalimat, penyusunan paragraf, penggunaan tanda baca dan ejaan, serta tepat dalam penulisan suku kata, sehingga karangan yang dihasilkan menjadi karangan yang baik dan benar serta layak untuk dibaca.

Berdasarkan hasil observasi yang dilakukan peneliti di peroleh informasi melalui wawancara dari teman sejawat yang pernah mengajar di kelas V SD Negeri 101797, serta beberapa keterangan dari guru kelas yang mengatakan bahwa di kelas V SD Negeri 101797
Kelurahan Delitua Induk Kabupaten Deli Serdang yang menunjukkan bahwa siswa kelas V tersebut belum mampu menulis teks deskripsi dengan baik, dimana dijelaskan bahwa ketuntasan dari perolehan nilai pada materi menulis teks deskripsi masih sangat kurang dan jauh dari harapan. Hal ini tentunya kurang memuaskan mengingat menulis merupakan kompetensi dasar yang harusnya dikuasai siswa mulai dari kelas IV Sekolah Dasar.

Beberapa faktor tertentu yang memengaruhi kurangnya kemampuan menulis teks deskripsi siswa tersebut antara lain: masih kurangnya pemahaman siswa mengenai teks deskripsi, minimnya perbendaharaan kosakata siswa , lemahnya kemampuan siswa dalam menganalisis, hal ini merupakan beberapa kendala yang menghambat berkembangnya kemampuan menulis siswa khususnya menulis teks deskripsi. Selain beberapa faktor yang berasal dari siswa, kurangnya kemampuan siswa dalam menulis teks deskripsi juga di pengaruhi oleh peran guru mengajar di dalam kelas. Masalah tersebut antara lain guru belum mampu memilih model maupun strategi pembelajaran yang tepat dalam menyajikan pelajaran kepada siswa, hal ini mengakibatkan terciptanya kegiatan belajar mengajar yang monoton dan membosankan serta mengakibatkan terhambatnya pencapaian tujuan pembelajaran. Perlu diciptakan kondisi belajar yang menyenangkan dan mampu 
mengembangkan daya pikir siswa serta dapat memotivasi siswa untuk belajar lebih aktif dan kreatif sehingga setiap dalam pembelajaran khususnya dalam pembelajaran Bahasa Indonesia siswa tidak terlihat pasif melainkan guru dan siswa sama-sama aktif saat pembelajaran berlangsung sehingga kemampuan belajar siswa dalam menulis dapat lebih baik dari sebelumnya. Hal ini dapat diciptakan melalu pemilihan model yang tepat salah satunya adalah model Example Non Example.

Huda (2014:234) Example Non Example merupakan model pembelajaran yang menggunakan gambar sebagai media untuk menyampaikan materi pelajaran.Strategi ini bertujuan mendorong siswa untuk belajar berpikir kritis dengan memecahkan permasalahan-permasalahan yang termuat dalam contoh-contoh gambar yang disajikan.Penggunaan media dirancang agar siswa dapat menganalisis gambar tersebut untuk kemudian dideskripsikan secara singkat perihal isi dari sebuah gambar. Maka peneliti tertarik intuk melakukan penelitian berjudul "Meningkatkan Kemampuan Menulis Teks Deskripsi dalam Pembelajaran Bahasa Indonesia Melalui Model Example Non Example di Kelas V SD Negeri 101797 Kelurahan Delitua Induk Kab. Deli Serdang Tahun Ajaran 2016/2017".

METODE PENELITIAN
Jenis penelitian ini adalah Penelitian Tindakan Kelas (Classroom Action Research) dengan menggunakan model Example Non Example sebagai sasaran utama dimana penelitian ini berupa pemaparan upaya meningkatkan kemampuan menulis siswa pada pokok bahasan Teks Deskripsi dikelas V SD Negeri 101797 Delitua dan dilaksanakan pada semester genap Tahun ajaran 2016/2017 yaitu bulan Januari sampai dengan Maret 2017.

Adapun cara menganalisis data menggunakan data persentase. Analisi data persentase ini dilakukan untuk mengetahui berhasil atau tidaknya tindakan yang dilaksanakan dengan rumus sebagai berikut:

a. Nilai Perolehan Individual (Sudjono, 2005:315)

$$
\begin{aligned}
& \mathrm{PPH}=\frac{\text { jumla } h \text { skor } \text { yang diperole } h}{\text { jumla } h \text { skor total }} \\
& \text { x } 100 \% \\
& \text { Dimana: } \\
& \mathrm{PPH}=\text { persentase penilaian } \\
& \mathrm{B}=\text { skor yang diperoleh } \\
& \mathrm{N}=\text { skor total }
\end{aligned}
$$

Kriteria keberhasilan:

$$
\begin{array}{ll}
0-54 & =\text { sangat tidak mampu } \\
55-64 & =\text { tidak mampu } \\
65-79 & =\text { cukup mampu } \\
80-89 & =\text { mampu } \\
90-100 & =\text { sangat mampu }
\end{array}
$$

b. Nilai Perolehan Klasikal

Rosmala Dewi (2015:126)

$\mathrm{P}=\frac{f}{n} \times 100 \%$

Keterangan:

$\mathrm{P}=$ angka presentasi 
Eva Betty Simanjuntak, Lili Husaini ......

$\mathrm{F} \quad=$ jumlah siswa yang $\quad \mathrm{N}=$ jumlah seluruh siswa mengalami perubahan

\section{HASIL PENELITAN DAN PEMBAHASAN}

Tabel Kemampuan Belajar Siswa

\begin{tabular}{|l|c|c|c|}
\hline No & Kemampuan & Nilai rata-rata & Keterangan \\
\hline 1 & Tes Awal & 50,3 & Sangat rendah \\
\hline 2 & Siklus I & 62,6 & Rendah \\
\hline 3 & Siklus & 70,2 & Sedang \\
\hline
\end{tabular}

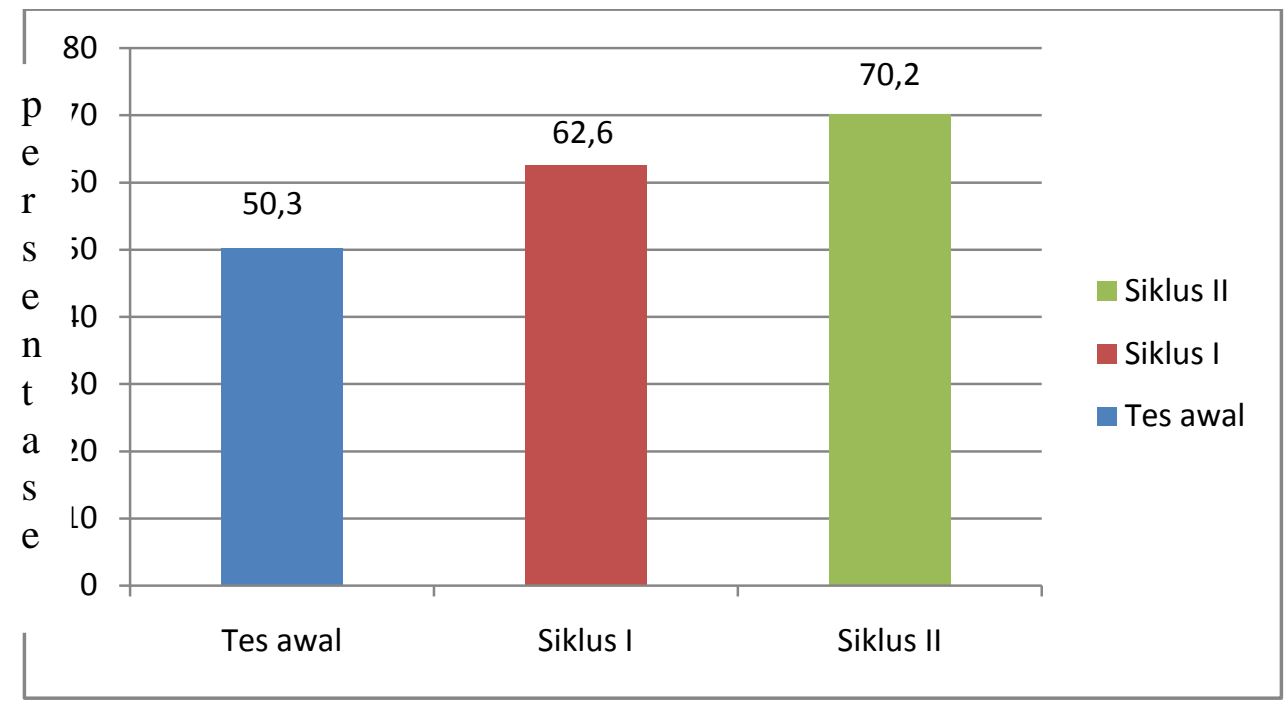

Gambar Nilai Rata-rata Peningkatan Hasil Kemampuan Tes Awal, Siklus I, dan Siklus II

Tabel Hasil Observasi Kemampuan Mengajar Guru

\begin{tabular}{|l|c|c|c|c|}
\hline No & Kemampuan & Skor & Persentase & Keterangan \\
\hline $\mathbf{1}$ & Siklus I & $\mathbf{3 3}$ & $\mathbf{7 5 , 0 0}$ & Cukup \\
\hline $\mathbf{2}$ & Siklus II & $\mathbf{3 9}$ & $\mathbf{8 8 , 6 3}$ & Baik \\
\hline
\end{tabular}

Kemampuan guru dalam jelasnya dapat dilihat pada mengaja rmengalami peningkatan gambar diagram batang dibawah disetiap siklusnya, untuk lebih ini:

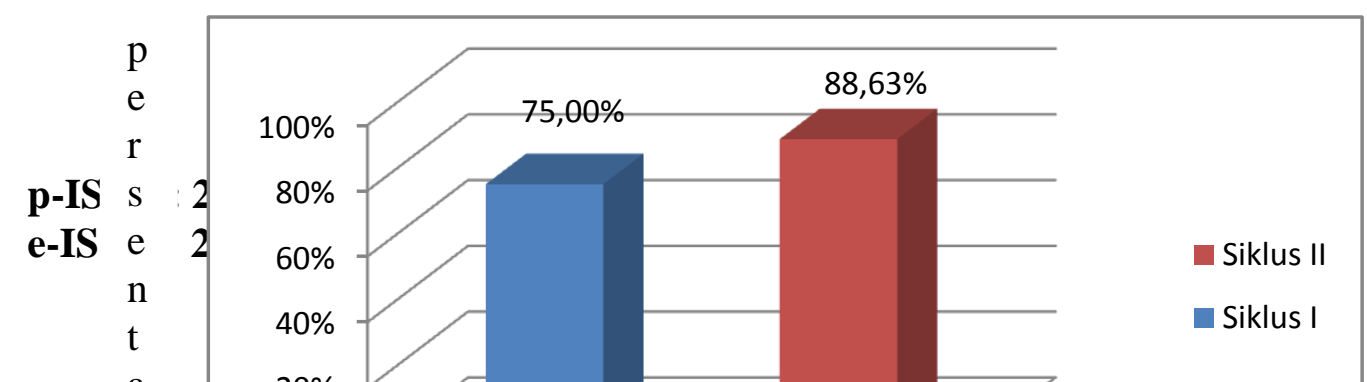


Gambar Diagram perbandingan hasil Observasi Pengajaran Guru Siklus I dan Siklus II

Tabel Hasil Observasi Aktivitas Belajar Siswa

\begin{tabular}{|l|c|c|c|c|}
\hline No & Kemampuan & Skor & Persentase & Keterangan \\
\hline $\mathbf{1}$ & Siklus I & $\mathbf{3 0}$ & $\mathbf{7 0 , 4 5 \%}$ & cukup \\
\hline $\mathbf{2}$ & Siklus II & $\mathbf{3 6}$ & $\mathbf{8 1 , 8 1 \%}$ & Baik \\
\hline
\end{tabular}

Kemampuan guru dalam jelasnya dapat dilihat pada mengajar mengalami peningkatan gambar diagram batang dibawah disetiap siklusnya, untuk lebih ini:

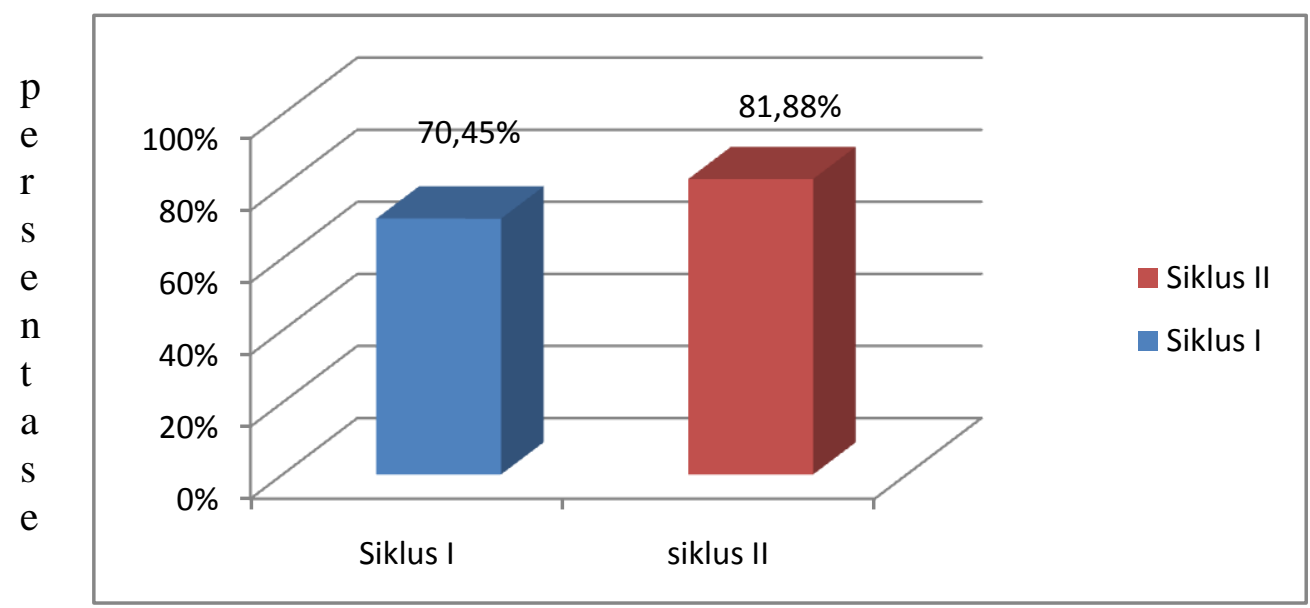

Gambar Diagram Perbandingan Hasil Observasi Aktivitas Belajar Siswa Siklus I dan Siklus II

Hasil penelitian pada tes awal siswa sebelum diberikan tindakan diperoleh nilai rata-rata 50,34dimana terdapat jumlah siswa yang sangat 
tidak mampu dalam menuliskan teks deskripsi yaitu sebanyak 22 orang siswa atau $73,3 \%$ dan siswa yang tidak mampu sebanyak 1 orang siswa atau 3,3\% sedangkan siswa yang cukup mampu menuliskan teks deskripsi sebanyak 7 orang siswa atau 23,4\%. Maka dapat disimpulkan kemampuan siswa dalam menuliskan teks deskripsi masih sangat rendah, dengan nilai rata-rata 50,34.

Setelah diberikan tindakan melalui model Example non Example pada siklus I terdapat peningkatan nilai rata-rata siswa sebanyak $40 \%$ dari nilai rata-rata awal $23,3 \%$ menjadi $63,3 \%$ pada siklus I. Serta jumlah persentasi hasil kemampuan siswa dimana jumlah siswa yang sangat tidak mampu sebanyak 11 orang siswa $(36,7 \%)$ dan yang cukup mampu sebanyak 18 orang siswa (60\%) sedangkan yang dikatakan mampu sebanyak 1 orang siswa $(3,3 \%)$. Berdasarkan hasil pada siklus I ini maka di peroleh bahwa terjadi penurunan siswa yang tidak mampu sebanyak $36,6 \%$, di mana pada tes awal siswa yang sangat tidak mampu menuliskan teks dekripsi sebanyak 22 orang(73,3\%) pada siklus I menurun menjadi 11 orang (36,6\%). Dan terjadi peningkatan pada siswa dengan kategori penilaian cukup mampu dimana pada tes awal siswa yang cukup mampu sebanyak 7 oarang $(23,4 \%)$ sedangkan pada siklus I meningkat menjadi 18 orang $(60 \%)$, artinya terjadi peningkatan sebanyak $36,6 \%$.
Berdasarkan hasil analisis siklus I dapat diperoleh kesimpulan sementara bahwa melalui model Example non Example masih kurang dapat meningkatkan kemampuan menulis teks deskripsi siswa sehingga perlu perbaikan dan pengembangan pembelajaran pada siklus II yang merupakan perbaikan dan pengembangan dari siklus I. Setelah melakukan pengulangan atau melaksanakan siklus II maka diperolehlah peningkatan nilai ratarata siswa sebanyak $20 \%$ dari nilai rata-rata awal $63,3 \%$ menjadi 83,3\%.Dengan perolehan hasil kemampuan siswa dimana jumlah siswa yang sangat tidak mampu sebanyak 3 orang siswa (10\%), tidak mampu sebanyak 2 orang siswa (6,7\%), cukup mampu sebanyak 19 orang siswa $(63,3 \%)$, dan siswa yang mampu sebanyak 6 orang siswa (20).

- Berdasarkan hasil pada siklus II ini maka di peroleh bahwa terjadi penurunan siswa yang tidak mampu sebanyak 26,6\%, di mana pada tes pada siklus I siswa yang sangat tidak mampu menuliskan teks dekripsi sebanyak 11 orang $(36,7 \%)$ pada siklus II menurun menjadi 3 orang (10\%). Dan terjadi peningkatan pada siswa dengan kategori penilaian cukup mampu dimana pada tes siklus I siswa yang cukup mampu sebanyak 18 oarang (60\%) sedangkan pada siklus II meningkat menjadi 19 orang $(63,3 \%)$, artinya terjadi peningkatan sebanyak $3,3 \%$ dan siswa dengan kategori mampu dalam menuliskan teks deskripsi juga meningkat 
sebanyak $16,7 \%$ dari hasil sebelumnya dimana pada siklus I siswa yang dikategorikan mampu hanya 1 orang $(3,3 \%)$ sedangkan pada siklus II menjadi 6 orang siswa (20\%).

Peningkatan juga terjadi pada aktivitas belajar siswa dimana hasil perbandingan aktivitas belajar siswa selama kegiatan belajar mengajar berlangsung di kelas menunjukkan siklus I mendapat $70,45 \%$ dengan kategori penilaian cukup, sedangkan pada siklus II mendapat $81,81 \%$ dengan kategori penilaian baik. Maka dapat kita lihat selisih peningkatan hasil observasi guru dalam mengajar pada siklus I dan siklus II sebesar $11,36 \%$. Hal ini berarti pembelajaran dengan menggunakan model example non example dapat meningkatkan kemampuan menulis teks deskripsi siswa serta meningkatkan aktivitas belajar siswa dalam melaksanakan kegiatan belajar mengajar.

\section{Pembahasan}

Dengan demikian dapat disimpulkan bahwa kemampuan menulis teks deskripsi siswa melalui model Example non Example dapat meningkat, dan model pembelajaran Example Non Example ini dapat dijadikan alternatif dalam meningkatkan kemampuan menulis siswa di Sekolah Dasar. Hal ini juga sesuai dan relevan dengan hasil penelitian dari penelitian sebelumnya, yaitu jurnal penelitian dari Suryani (2013) yang merupakan mahasiswa dari Universitas
Muhammadiyah Surakarta yang berjudul "Peningkatan Keterampilan Menulis Karangan Deskripsi Melalui Stategi Example Non Examples Pada Siswa Kelas IV SD Negeri II Setrorejo Tahun Ajaran 2012/2013 Pada Mata Pelajaran Bahasa Indonesia" Berdasarkan hasil penelitian tindakan kelas yang telah dilaksanakan dalam dua siklus pada peserta didik, siswa kelas IV SDN II Setrorejo yang

Hasil penelitian tindakan
kelas menunjukkan bahwa keterampilan menulis siswa mengalami peningkatan yaitu sebelum adanya tindakan kelas hasil belajar siswa yang di atas KKM sebelum tindakan sebanyak 9 siswa (45\%), 14 siswa (70\%) pada siklus I, dan 18 siswa (90\%) pada siklus II. Penelitian ini menyimpulkan bahwa pembelajaran bahasa indonesia melalui model Example Non Examples dapat meningkatkan keterampilan menulis karangan deskripsi yang berdampak pada peningkatan hasil belajar siswa.

Selanjutnya penelitian dari Setia, Getmi Purnama mahasiswa dari Universitas Pendidikan Indonesia tahun 2016 dalam penelitiannya yang berjudul "Penggunaan Model Pembelajaran Example Non Example Dalam Meningkatkan Kemampuan Menulis Karangan Deskripsi" dimana dalam penelitiannya yang merupakan Penelitian Tindakan Kelas (PTK)" dengan berdasarkan data temuan sebelum menggunakan model pembelajaran Example Non Example 
pada tahap prasiklus nilai yang diperoleh siswa masih banyak di bawah KKM dengan rata-rata nilai 66. Setelah menerapkan model Example Non Example diketahui bahwa aktivitas belajar mengajar guru, siswa dan nilai hasil tes siswa setiap siklus meningkat dengan ratarata nilai yang diperoleh 80 dari 33 siswa. Maka dapat disimpulkan bahwa penggunaan model pembelajaran example non example dapat meningkatkan kemampuan menulis karangan deskripsi siswa kelas IV SD Negeri Serang 11. Dari beberapa hasil penelitian di atas tentu dapat mendukung atau menunjukkan bahwa model Example non Example dalam pembelajaran Bahasa Indonesia Khususnya materi Menulis karangan atau teks deskripsi dapat meningkatkan kemampuan menulis siswa-siswa pada bangku sekolah dasar dengan model yang berfokus pada tingkat analisis siswa tersebut sehingga siswa lebih mudah dan cenderung semangat dalam melaksanakan kegiatan belajar mengajarnya.

Berdasarkan penelitian yang dilakukan oleh peneliti selama proses pembelajaran, maka dapat disimpulkan bahwa melalui model Example Non Example dapat meningkatkan kemampuan menulis teks deskripsi siswa pada pembelajaran Bahasa Indonesia di kelas V SD Negeri 101797 Delitua Induk Tahun Pelajaran 2016/2017, meskipun masih ada beberapa siswa yang belum mampu memeperoleh hasil belajar yang diharapkan.
Hal ini terjadi atas beberapa faktor diantaranya siswa masih enggan mengikuti pelajaran sesuai intruksi yang diberikan guru, siswa masih kurang aktif dalam kegiatan belajar mengajar, siswa belum berani mengungkapkan pertanyaan maupun pendapatnya secara langsung dan tegas, serta siswa masih kurang mampu dalam pengorganisasian karangan serta pemilihan kalimat, ataupun suku kata yang baik dan benar dalam penulisannya. Adapun faktor pendukung sehingga dikatakjan bahwa pembelajaran ini berhasil dan kemampuan menulis siswa juga meningkat dikarenakan siswa memiliki kemauan dalam bejaran, aktif dalam bertanya, serta sudah mampu memahami cara menulis teks deskripsi yang baik dan bedar sesuai dengan indikator yang ditetapkan.

\section{SIMPULAN}

Penelitian dalam peningkatan kemampuan menulis teks deskripsi melalui model Examle Non Example di SD N 101797 Deli Tua Induk telah dilaksanakan sesuai dengan ketentuan serta prosedur yang telah ditetapkan, berdasarkan aspek-aspek menulis yang meliputi isi karangan, organisasi karangan, penggunaan bahasa, hingga penggunaan ejaan dan tanda baca. Berdasarkan hasil analisis data dan pembahasan maka diperoleh kesimpulan bahwa penggunaan model Example non Example dapat meningkatkan kemampuan menulis teks deskripsi siswa pada pembelajaran Bahasa 
Indonesia di kelas V SD Negeri 101797 Delitua Tahun Pelajaran 2016/2017, penelitian terdiri dari dua siklus tiap siklus terditi dari 2 pertemuan. Penelitian ini menggunakan analisis data tes dan observasi, kemampuan menulis teks deskripsi meningkat dengan rincian perolehan rata-rata yaitu, tes awal nilai rata-rata sebesar 50,34 dan meningkat pada siklus I menjadi 62,63 kemudian pada siklus II meningkat sebesar 70,2, hasil observasi guru siklus I mendapat $70,45 \%$, sedangkan pada siklus II mendapat $81,81 \%$ dengan kategori penilaian baik. Maka dapat kita lihat selisih peningkatan hasil observasi guru dalam mengajar pada siklus I dan siklus II sebesar 11,36\%. Dengan kata lain setelah dilakukan tindakan pembelajaran dengan model Example non Example dapat meningkatkan kemampuan menulis teks deskripsi siswa kelas V SD Negeri 101797 Delitua TP 2016/2017.

\section{DAFTAR RUJUKAN}

Dalman. 2012. Keterampilan Menulis. Jakarta: Raja Grafindo Persada.

Dalman. 2015. Penulisan Populer. Jakarta: Raja Grafindo Persada.

Dewi, Rosmala. 2015. Profesional Guru melalui Penelitian Tindakan Kelas. Medan: Unimed Press.

Friedman, L.S. 2010. Writing The Critical Essay: Euthanasia. Farmington Hills: Green haven Press.

Huda, Miftahul. 2014. Model-Model Pengajaran dan Pembelajaran. Yogyakarta: Pustaka Pelajar.

Nurgiyantoro, Burhan. 2013. Penilaian Pembelajaran Bahasa Berbasis Kompetensi. Yogyakarta: BPFE.

Suparno dan Mohamad Yunus. 2008. Keterampilan Dasar Menulis. Jakarta: Universitas Terbuka.

Trianto. 2011. Mendesai ModelModel Pembelajaran InovatifProgresif. Jakarta: Kencana.

Purnama, Getmi. 2012. Peningkatan

Keterampilan

Menulis

Paragraf Deskripsi Dengan Model Examples Non Examples Melalui Media Video Compact Disc (VCD). Semarang. Jurnal Pendidikan Indonesia. Vol 4, No. 4:49-61. 